\title{
DECREASING AVERAGE COST AND COMPETITION: A NEW LOOK AT THE ADDYSTON PIPE CASE*
}

\author{
GEORGE BITTLINGMAYER \\ University of Michigan
}

I. INTRODUCTION

L EGAL scholars know Addyston Pipe as one of three or four turnof-the-century cases that established how the Sherman Act was to be applied to cartel agreements. Judge William Howard Taft's highly regarded court of appeals opinion in Addyston ${ }^{1}$ not only reinforced the tendency, already apparent in Joint Traffic, to regard horizontal price fixing as per se illegal but also provided a way of distinguishing presumably harmful cartel agreements from those agreements, like partnerships, that promote the public good. "Given the time at which it was written," writes Robert Bork, "Addyston must rank as one of the greatest, if not the greatest antitrust opinions in the history of the law." 2

Industrial organization economists are also familiar with the case, and very nearly to a man they regard the agreement among the cast-iron pipe producers who were the defendants in Addyston as an example of the classic manufacturers' cartel which the antitrust laws have largely eliminated or driven underground. The unfavorable assessment of behavior in

* This study is based on my dissertation, Competition and the Nature of Costs: The Cast Iron Pipe Industry, 1890-1910, and the Case of Addyston Pipe (University of Chicago, 1981). I am indebted to Lester Telser, my thesis chairman, for his generous advice on the topics covered in this study. I also thank Richard Posner and Sherwin Rosen for serving on my committee and for their interest in Addyston. Members of the workshop in Applied Price Theory at Chicago and the referee for this Journal provided helpful comments, and Yale Brozen brought the case to my attention and encouraged my work on it. Financial support for this work came from the Liberty Fund, the Winchester Foundation, and the Charles R. Walgreen Foundation, and I thank these organizations for their help. A special thanks is owed to United States Pipe and Foundry, which provided the data. For other aspects of this topic, see my forthcoming article, Price Fixing and the Addyston Pipe Case, 5 Research L. \& Econ. (1983).

1 U.S. v. Addyston Pipe and Steel Co., 85 Fed. 271 (6th Cir. 1898).

2 Robert Bork, The Antitrust Paradox: A Policy at War with Itself (1978) at 26.

[Journal of Law \& Economics, vol. XXV (October 1982)]

(C) 1982 by The University of Chicago. All rights reserved. 0022-2186/82/2502-0010\$01.50 
this industry has been reinforced by the fact that the six firms found guilty of price fixing merged while their case was on appeal. This merger appears to have gone unnoticed at the time, perhaps because of the simultaneous wave of mergers in manufacturing generally. But when the merger of the Addyston defendants was discovered and commented on many years later, it was interpreted, by implication anyway, as vindication of the 1904 Northern Securities decision dealing with merger for monopoly and of at least some parts of the subsequent legislation restricting horizontal mergers. ${ }^{3}$

The aim of this study is to provide a more detailed analysis of costs in the cast-iron pipe industry and to propose what may appear to be a novel explanation for the cartelization and merger. This explanation has its modern roots in recent developments in economic theory, including economic game theory and the theory of the core. It is also related to the theory of natural monopoly.

The most startling result to emerge from work in this area is that, barring only a few special cases, there is no competitive equilibrium in an industry composed of independently operated plants with identical, $\mathrm{U}$-shaped average cost curves. The cost conditions are, of course, those from the textbook case of the Viner industry, but I think many if not most economists are surprised that this ineluctable result concerning equilibrium is contained in the most familiar of models. A broader and more practical result is that there is no competitive equilibrium in an industry characterized by quite plausible cost and demand conditions. All we need for this conclusion is falling long-run average cost, stochastic demand, and some cost associated with having idle plants. An implication of these largely negative results concerning competition is that some noncompetitive, cooperative solution to market allocation is necessary. By extension, the importance of this line of reasoning for antitrust is that it becomes unrealistic to expect competitive behavior in certain markets because firms could not behave competitively even if they wanted to.

While the view that there cannot be a competitive equilibrium in a

${ }^{3}$ Simon N. Whitney, Antitrust Policies in Twenty Industries, vol. 2 (1958) was the first to look beyond the case and the related court documents and the first to discuss the merger and subsequent developments at any length. Earlier treatments are either brief commentaries based on what appears in the Federal Reporter or excerpts from court documents. Among these are William Z. Ripley, ed., Trusts, Pools and Corporations (1905), William Stevens, ed., Industrial Combinations and Trusts (1914), and Henry R. Seager and Charles A. Gulick, Jr., Trust and Corporation Problems (1929). Almarin Phillips, Market Structure, Organization and Performance (1962), devotes one chapter to the industry and case and presents some new and useful material. As far as I know, the merger was first mentioned in connection with the case by Wendell Berge in an unpublished address before the sixtieth annual convention of the American Economic Association (held in Chicago in December 1947). See the Report of the Federal Trade Commission on the Merger Movement (1948) at 8-9. 
market may appear novel, it is in fact closely related to the way Alfred Marshall, J. M. Clark, and other economists looked at short-run pricing in a market. Marshall made a special effort to point out that the notion of competitive equilibrium was to be interpreted only as a long-run concept, and Clark devoted several of his works to advancing the view that marginal cost pricing-which is what competition implies-would not enable firms to recover their costs. There was, in fact, a general concern among economists in the period before World War II with "ruinous" and "cutthroat" competition and with the question of stability in markets. Unfortunately, interest in these topics, at least with a view toward application, has largely dried up since the late forties. It is true that our understanding of the related issue of natural monopoly pricing has increased, and this is partly due to the substantial effort devoted to a reconciliation of the appropriate marginal conditions with the goal of making natural monopolies pay their own way. ${ }^{4}$ But it has not been generally recognized that the most fruitful distinction between a natural monopoly and many other industries is one of degree and not kind, and, consequently, that these other industries must themselves settle problems which the theory of natural monopoly says have no competitive solution and with which the regulatory bodies deal only imperfectly.

So, while the implication of increasing returns or nonconvexity for market equilibrium has been explored in theoretical research, there has been no general recognition that the difficulties that arise in economic models have their counterpart in real markets. When most economists imagine a price-fixing conspiracy, I think they have at the back of their minds the competitive market model in which traders either have convex preferences (this implies no increasing returns for sellers) or have nonconvex preferences but are small relative to the market. In the first case, it turns out that the assumption of small numbers, which makes the idea of collusion manageable, poses no necessary obstacle to competition. In the second case, however, the assumption of small numbers is a serious inconsistency and is incompatible with competition. These observations suggest that explicit cartelization, tacit collusion, and horizontal merger can be viewed, in many instances, as the noncompetitive arrangements that the firms in an industry must necessarily adopt. Whether the resulting arrangements are in any sense optimal is another matter, and in some cases it may turn out to be correct to substitute government regulation or

\footnotetext{
${ }^{4}$ Ronald H. Coase, The Marginal Cost Controversy, 13 Economica 169 (1946), presents the arguments in favor of such a reconciliation and advocates multipart pricing. William J. Baumol, Quasi Optimality: The Price We Must Pay for a Price System, 87 J. Pol. Econ. 578 (1979), shows that, from a global view, constant unit prices will in general imply a loss of welfare. For a summary of the modern natural monopoly literature see W. W. Sharkey, The Theory of Natural Monopoly (1982).
} 
ownership for self-regulation. An adequate discussion of this issue would involve a review of the theory of the firm and other topics that are best left to a separate treatment.

The plan of this study is as follows. Sections II and III present a brief summary of the relevant economic theory. This theory emphasizes the stringent conditions necessary for a competitive equilibrium and shows that competitive, marginal-cost pricing is not in general feasible in an industry characterized by increasing returns. Section IV describes the technology of cast-iron pipe production and suggests how the nature of this technology affects short- and long-run costs. Sections V and VI examine detailed accounting records for eleven cast-iron plants, including five of the six Addyston defendants. Cost data of this sort are extremely rare, even for a famous antitrust case; but the results by and large confirm, not the economist's textbook drawing of cost curves, but rather the businessman's idea of how costs behave. Some expenses are largely fixed and do not vary with output; others vary directly with output but with no hint of increasing marginal cost over observed output ranges. This last finding does not imply irrationality but is consistent with the view that the optimal industry response to uncertainty entails slack capacity, at most times. Section VII presents estimates of short-run cost functions and takes into account an important source of bias. Finally, Section VIII presents the conclusions. Let me add that I do not take up the events in this industry directly. The emphasis is on the conditions necessary for competition and on the nature of costs.

\section{Competition in Viner Industries}

The classic market model is characterized by a fundamental and longrecognized instability, which is illustrated in Figure 1. Consider an industry composed of two plants that have the familiar U-shaped average cost curves. Marginal cost in this industry is a discontinuous function of total industry output and is equal to the minimum average cost of the plants at two points, $Q_{1}$ and $Q_{2}$. Suppose that the rate of demand faced by this industry is given by the curve labeled $D$. Will industry equilibrium call for the operation of one or of two plants? If two plants are operating, competition will result in a price equal to marginal cost; but since marginal cost is less than average cost, both plants will incur losses. If one plant shuts down, the remaining one will make profits. But this makes it possible for the idle plant to strike a bargain with the buyers who are paying high prices, thereby undercutting the active plant. It should be clear that an increase in demand and in the number of firms does not alter the problem 


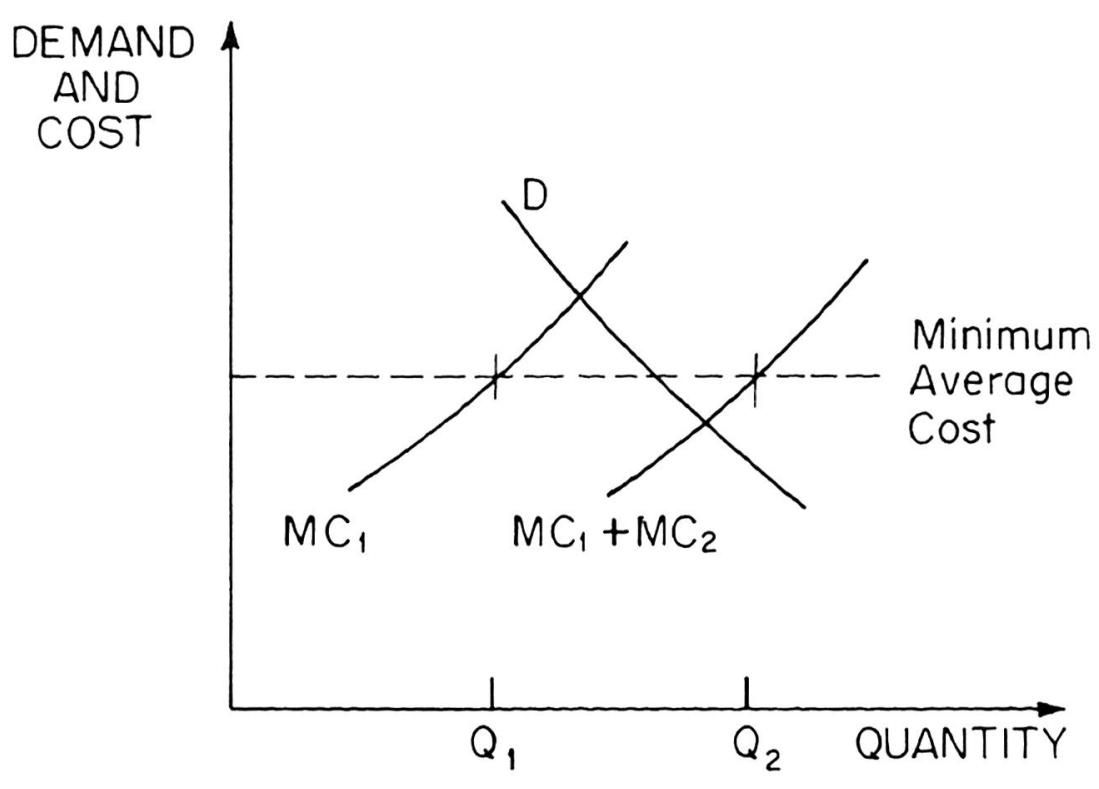

Figure 1

in any fundamental way, at least not until the number of firms becomes very large.

Jacob Viner, who developed the analysis of industries with U-shaped average cost curves, was apparently aware of this problem. In his classic expository article, "Cost Curves and Supply Curves," Viner considers the case in which there are constant industry costs because all existing firms and an indefinite number of potential entrants face the same long-run average cost curve (which has a minimum). "Here . . . actual long-run price and output for the industry would oscillate above and below stable points of equilibrium price output." ${ }_{5}^{5}$ Judging by this comment and an elaboration of the same point in the next paragraph, Viner appears to be addressing the same issue.

Lester Telser has recently made a detailed investigation of equilibrium in this familiar market model, using the theory of the core. ${ }^{6}$ It turns out that no competitive equilibrium exists for almost all rates of demand if plants have identical $U$-shaped average cost curves. An exception occurs if demand is such that it crosses the marginal cost curve at a point where marginal cost equals average cost, which implies that plant cost functions

5 Jacob Viner, Cost Curves and Supply Curves, 3 Zeitschrift für Nationalökonomie 23 (1931), reprinted in George J. Stigler and Kenneth Boulding, eds., Readings in Price Theory (1952) at 212. This passage in Viner is discussed in Lester Telser, Economic Theory and the Core (1978) at 387. The earliest work to focus on this topic, rather than treating it as a loose end as Viner does, appears to be George Cady, Entrepreneural [sic ] Costs and Price (1942).

${ }^{6}$ Lester Telser, supra note 5, at 106-16. 
exhibit constant returns to scale at that point. William Baumol arrives at similar conclusions in his discussions of optimal pricing in a world that exhibits increasing and decreasing returns. ${ }^{7}$

\section{Competition in Industries with Uncertain Demand and INCREASING RETURNS}

The results in the previous section are clear and straightforward. No competitive equilibrium exists for almost any rate of demand in an industry whose firms have identical U-shaped average cost curves. More difficult problems arise when we want to employ a theoretical structure that bears some resemblance to the facts we actually encounter. Specifically, we would like to be able to analyze the combined influence of uncertainty and increasing returns. We will take uncertainty to apply only to demand, because this approach illuminates the problem without needless complications. Increasing returns over some range are also a necessary ingredient in our analysis, and indeed it would be foolhardy to deny the practical importance of increasing returns. Decreases in the scale of operation of every sort of economic activity, from the production of steel to the production of chocolate chip cookies, will eventually result in higher average cost. But attached to this important fact of life is an equally important observation: a size distribution of plants covering an appreciable range is consistent with increasing returns over that range. The optimal use of resources under uncertainty will imply the use of large, efficient plants as well as small, inefficient ones. Whether we will in fact see the optimal distribution emerge in an industry is another matter, although the evidence indicates that something like it does emerge.

The results presented below are drawn from work by William Sharkey and Telser, and the interested reader is directed there for a fuller treatment. ${ }^{8}$ The concern here will be to provide a summary of those theoretical results that provide insight into the apparent failure of competition in the cast-iron pipe industry. Specifically, it turns out that if plants have avoidable costs related to capacity - that is, lump-sum costs that are incurred at positive output rates but not if output is zero-and if there are fixed costs to having plants so long as they exist, then competitive solutions are not possible in the short run (the period for which the decision to shut dow $n$ is made). A related finding is that decreasing long-run average costs in the industry will prevent firms from recovering their expenses under the optimal output paths if they are restricted to short-run marginal cost pricing.

${ }^{7}$ William Baumol, supra note 4.

${ }^{8}$ William Walker Sharkey, A Study of Markets Involving Increasing Returns and Uncertain Demand (Ph.D. diss., Univ. of Chicago, 1973) and Telser, supra note 5, at ch. 2. 
Sharkey's analysis is based on a market in which plants incur fixed costs, $f+g q$, where $f$ and $g$ are constants and $q$ is plant capacity. Plants also incur lump-sum avoidable costs at positive output rates that are linear homogeneous functions of capacity. Two results concerning the correct industry response are of interest. First, the optimal collection of plants if the probability distribution of the number of identical demanders is uniform and restricted to the interval $[0, R]$ will call for a size distribution of plants such that each plant is twice as large as the next. In addition, as fixed costs increase, the optimal solution calls for a smaller number of plants. More general results would be desirable, but unfortunately the analytical difficulties make progress difficult. There is to date no general solution to the problem of the optimal size distribution of plants in a Viner industry with $U$-shaped or declining long-run average cost and uncertain demand. ${ }^{9}$ One important general observation to emerge from this work, however, is that if fixed costs are zero, then an infinite number of plants of different sizes is costlessly available. Thus, any particular level of demand could be met with one active plant operating at full capacity. Under more realistic circumstances it will be necessary for plants to operate below capacity or for some demand in excess of minimum average cost to go unsatisfied. It is this that sets the stage for Sharkey's second major result, namely, that there is no competitive equilibrium for almost all rates of demand that call for two or more plants. The fundamental difficulty is that the globally optimal solution, which normally calls for some slack capacity at active plants or some unsatisfied demand in excess of minimum average cost because of the limited number of plants, is incompatible with the desire of plant owners and buyers to realize the gains from operating plants at minimum average cost, which is the locally optimal solution. The more familiar statement is that competition for buyers prevents plants from covering their costs.

Transportation and heavy manufacturing industries provide a rich source of examples that have this sort of cost structure and the problems that go with it. Consider the production of cement, an activity that is characterized by uncertain demand, economies of scale, and substantial avoidable costs. For simplicity assume that the several plants serving an area are located close enough together so that differences in transportation cost to their customers are negligible. (This is not a crucial assumption. It is an easy matter to construct examples with dispersed plants and customers that have the same results.) Under arbitrary, realized rates of

\footnotetext{
${ }^{9}$ Obviously, similar technical problems concerning the optimal size distribution of plants arise if demand is certain and variable. If demand is fixed, the optimal size distribution of plants in the case of increasing returns calls for one large plant.
} 
demand, marginal cost pricing will often result in prices that are too low to cover all costs, even only the variable costs of production. The basic problem is that it is not possible to change plant sizes costlessly to run at minimum average cost for any particular rate of demand. Note that this would not necessarily thwart a competitive outcome if small plants were not more expensive to operate than large ones. In fact, it is possible for firms to compete and recover their costs in the case of uncertain demand if there are constant returns and, therefore, no penalties for small plants. ${ }^{10}$

The third major result from this work by Sharkey and Telser on market equilibrium is that restrictions on recontracting will allow an equilibrium to emerge. A sufficient condition for the emergence of an equilibrium is that all supply or all demand be under the control of one agent. This restriction prevents one group composed of some plant owners and some buyers from undermining arrangements that cover costs. Theoretical results of this sort suggest that a variety of business practices that appear anticompetitive can be interpreted as attempts to achieve stabilization in a market. In an industry with seasonal fluctuations, for example, a firm may ask some of its buyers to commit themselves to buy all of a year's requirements from that firm. This was the case in the cast-iron pipe industry. Under other circumstances it can lead to state control of the enterprises or to state-sanctioned collusion. Of course, there may also be private-sector collusion in the form of price fixing or geographic restrictions on dealings. ${ }^{11}$

${ }^{10}$ See Eytan Sheshinski and Jacques H. Dréze, Demand Fluctuations, Capacity Utilization, and Costs, $66 \mathrm{Am}$. Econ. Rev. 731 (1976), for results based on the assumption that all plant cost curves are identical but the number of plants need not be an integer. It may in fact be useful to compare briefly some aspects of their analysis, in particular Section II ("Propositions for a Simple Model with Uncertain Demand"), with Sharkey's and Telser"s results summarized above. In Sheshinski and Dréze's model industry demand is a random variable with zero-price elasticity and "firms are set up before the level of output is known. Output is then allocated equally among firms." In other words, variations in industry demand are never met by shutting down plants. Also, the assumption of fractional plants with the same minimum average cost as whole plants implies constant returns. Based on these assumptions, they find that "competition," in the sense of individual profit maximizing behavior and free entry and exit in response to expected profits and losses, leads to the socially efficient allocations. However, it will not in general be possible to obtain this result if $(a)$ the number of identical plants is restricted to integer values (this is a special case of increasing returns), or (b) plant costs are such that it makes sense to shut plants down for particular realized rates of demand.

${ }^{11}$ The issues raised here are related to a more general question: Why do economic agents use the price system in some circumstances but not in others? The difficulties raised by increasing returns and fixed costs can be viewed as creating a variety of market failure that can be overcome with appropriate restrictions on the behavior of buyers and sellers, that is, with a partial suppression of the market. These difficulties can also be eliminated or reduced by vertical or horizontal integration, but these solutions may be more costly to implement (antitrust considerations aside). The modern theory of the firm, which suggests this ap- 
This kind of short-run analysis answers the question whether a competitive market can arise in an industry; once plants in an industry exist, will competition allow them to operate harmoniously? A related problem is whether firms can be induced to enter an industry with competitive pricing. The simplest case to analyze is the one in which industry costs are an increasing function of capacity and output. Take the special case where total industry costs are determined by the function $T C=K+K^{-\beta} c q^{2}$, where $K$ is the fixed cost incurred regardless of output, $c$ is a constant, and $q$ is current output. The second term on the right represents the variable costs. If there are two states of the world, and if marginal benefit (demand) in state 1 is $a_{1}-b q$ and in state 2 is $a_{2}-b q$, where $a_{1} \neq a_{2}$, then setting prices equal to short-run marginal cost will not in general lead to the recovery of costs under the optimal output path. In particular, if $\beta>$ 1 , which implies increasing returns, then this policy will lead to losses on average. This result is, of course, related to well-known conclusions from the natural monopoly literature. ${ }^{12}$

It is of course true that the possibility of storing output mitigates the problems faced by independent firms operating under increasing returns. For example, if it is costless to hold inventories, firms in a Viner industry facing uncertain demand could operate at minimum average cost and sell their output at a price equal to that cost. In practice, however, inventories are costly, and this calls for firms to meet varying demand in part by changing the rate of production. This is especially likely to be true in instances where output is not homogeneous, as it was in the case of castiron pipe because of the range of pipe sizes. In still other cases-the generation of electricity, for example-storing output is nearly impossible.

Now, while this conclusion concerning the feasibility of competition and the function of market collusion may appear to be out of step with much of economic thinking, the analysis is in fact closely related to other work in industrial organization. First, the view that competition is unstable was widely shared by economists in the 1920s and 1930s, and with a fairly good, albeit intuitive, recognition of the principles involved. ${ }^{13} \mathrm{Sec}$ -

proach, begins with Ronald Coase, The Nature of the Firm, 4 Economica 386 (1937) and has been elaborated by Oliver E. Williamson, Markets and Hierarchies (1975), among others.

${ }^{12}$ See, for example, Herbert Mohring, The Peak Load Pricing Problem with Increasing Returns and Pricing Constraints, 60 Am. Econ. Rev. 693 (1970). A detailed analysis of the conditions under which short-run marginal cost pricing allows the recovery of cost, together with implications for the status of the core, is provided by Telser, supra note 5, at 117-29.

${ }_{13}$ Alfred Marshall, for example, pointed out that a decline in demand could lead to marginal cost pricing but that prices seldom fall that low, both because of "fear of spoiling the market" and to allow producers to cover their general expenses. See Alfred Marshall, Principles of Economics (8th ed., 1920, reset and reprinted in 1949), at 311-13, as well as 
ond, the idea that complete freedom of contract is economically intractable, or at least inefficient, is actually fairly familiar. Most economists would agree that restrictions on transactions promote efficient outcomes in certain situations. For example, copyrights, patents, resale price maintenance, franchise agreements, and covenants not to compete prohibit certain forms of competition. The justification for these restrictions is that they allow certain types of socially beneficial expenses to be covered. Viewed in this light, the significance of the agreement and merger among the Addyston defendants may be that they provide an instance in which a competitive outcome could not be sustained and in which cartel restrictions promoted the production of a good by allowing firms to cover their costs.

\section{The Technology of Cast-Iron Pipe Production and SOME FACTS ABOUt THE INDUSTRY}

Clearly, our discussion of competition emphasizes the importance of costs. There are in fact several ways of investigating costs in this case. In this section I will look at some of the features of cast-iron pipe production that have a bearing on how costs vary with output for a given plant and with plant size. It also provides a summary of some basic facts concerning the industry that are relevant to competition. In Section V, I introduce the cost data provided by United States Pipe and Foundry for eleven turnof-the-century cast-iron pipe plants and suggest why a large fraction of these expenses do not vary in strict proportion to output. Sections VI and VII investigate how costs vary by plant size and how they vary with output. The chief results are that economies of scale do exist and that marginal costs over the observed output ranges were roughly constant and below average costs. Each of the three approaches-the analysis of production technology, the detailed examination of accounting records,

Book V passim. In his discussion of increasing returns Marshall argues that "the theory of equilibrium of normal demand and supply helps indeed to give definiteness to our ideas; and in its elementary stages does not diverge from the actual facts of life. . . But when pushed to its more remote and intricate logical consequences, it slips from the conditions of real life." $I d$. at 381-82. J. M. Clark had substantially the same view. "In theory, the same argument which is used to show how competition brings prices down to cost . . . can be used to prove conclusively that competition tends to force prices down to differential [marginal] cost, if existing productive capacity will supply the demand at that price. And as industry is in a chronic state of partly idle capacity, to insist that producers shall compete unchecked appears to amount to inviting competition, and private enterprise with it, to commit suicide." John Maurice Clark, Studies in the Economics of Overhead Costs (1923) at 135. Clark reiterated this point in Toward a Concept of Workable Competition, $30 \mathrm{Am}$. Econ. Rev. 241 (1940), where he noted that perfect competition requires average and marginal cost
to be equal. 
and statistical cost analysis-leads to the conclusion that the cost conditions in this industry are inconsistent with an unrestricted competitive equilibrium.

The process by which cast-iron pipe was manufactured is relatively simple and remained unchanged from the middle of the nineteenth century until the 1920s when centrifugal casting was adopted..$^{14}$ Pig iron was melted and poured into vertical sand-lined molds, and the cast pipe was dipped into a hot coal-pitch bath. The process required considerable amounts of fuel. Coke was used to melt the iron, coke and coal were used to dry the sand molds, and the cast pipes had to be heated to 300 degrees before being dipped in the coal pitch.

The maximum possible rate of output at a plant appears to have been governed by certain technical features. The cupolas in which the pig iron was melted had to be cooled off, cleaned, and repaired once a day after a maximum of twelve to sixteen hours of operation. Melting capacity at foundries was determined by the sizes and capacities of the cupolas and by the number of pits into which the molds could be placed while the iron solidified. Another operation that had some bearing on capacity was the drying of molds and cores (the two parts of the form into which the molten iron was poured). The number of forms that could be handled was limited by the sizes and capacities of the drying ovens. Molds were prepared one day, dried overnight, and used the next.

There are certain other technical considerations that deserve our attention. Data presented below suggest that large foundries enjoyed economies of scale. From what do these economies arise? A brief discussion of the cupola will illustrate the sorts of savings that are possible. A cupola is fundamentally a cylindrical furnace into which layers of pig iron and coke are placed. It is very efficient from a technical standpoint because the fuel is in direct contact with the metal. The layers are melted progressively from the bottom to the top, and the molten pig iron that collects at the bottom is tapped into a ladle. As molten iron is run off, new layers of iron and coke are placed on top of the old from an opening halfway up the side of the cupola.

It is clear that at least several workers were required for the continuous operation of a furnace. For units with daily capacities of only sixty to 100

14 The following summary of technology and market conditions comes from these sources: William D. Moore, Development of the Cast Iron Pressure Pipe Industry in the Southern States, 1800-1938 (1939); J. B. Nau, Metal Mixers for Pipe Foundries, The Iron Age, June 8, 1905, at 1824; Henry Jeffers Noble, History of the Cast Iron Pressure Pipe Industry in the United States of America (1940); John Shoup, Modern Foundry Practice (1900); William C. Stimpson and Burton L. Gray, Foundry Work (1944); and various documents contained in the Transcript of Record of the Supreme Court of the United States, October Term 1899, No. 51: Addyston Pipe and Steel v. the United States. 
tons, which we shall see is near the minimum efficient size, six men with separate duties attended a single cupola. But it does not seem plausible that doubling the cupola diameter would more than double the number of workers required to service it; in fact, one would expect a less than proportional increase. Yet doubling the diameter from thirty to sixty inches resulted in a three- to fourfold increase in the average melting rate because melting capacity depends on the surface area of the floor of the cupola, and this increases according to $\pi r^{2}$. On the other hand, to the degree that cleaning and relining costs and radiation heat loss depend on the surface area of the sides, these costs increase only in direct proportion to the diameter. If we let $h$ be the height of the cupola, then the surface area is directly proportional to the radius and equals $2 \pi r h$.

Obviously, then, there are good reasons why it might be cheaper per ton to melt 200 tons of pig iron each day rather than only 100 tons. Moreover, there are clear inefficiencies in the application of variable factors if we melt only 100 tons per day in a 200-ton furnace. Essentially the same crew will have to be used, although for a shorter period, since considerable waste resulted if a cupola of specific capacity was run at an hourly rate different from what it was designed for. Slag buildup and fuel waste were two major sources of inefficiency. It was also true that the start-up procedures and cleanup were largely unaffected by the size of the daily run. Thus, if only half the iron of a full-capacity run was melted, it is not at all likely that only half the labor and fuel costs were incurred. According to these observations, we should not be surprised to find that there are economies in the application of variable factors. ${ }^{15}$

The structure of the industry in 1890 is easily determined because the U.S. Census Office chose to make a special study of it for the census of that year. ${ }^{16}$ Thirty-six establishments were reported as primarily engaged in the manufacture of cast-iron pipe. Of these, two were not in operation the year of the census. The largest cluster of firms was in New Jersey and eastern Pennsylvania. Together, these two states had twelve of the thirty-six firms. This area had been the center of pipe production in the early years of the industry and still accounted for 43 percent of the U.S. production in 1890. Eleven of the fourteen plants in operation west and south of Ohio were constructed after 1880 . Nationwide, twenty of the thirty-six plants were built in that decade. A curious fact regarding the construction between 1880 and 1890 is that the new southern mills tended

15 Eliot Jones, The Principles of Railway Transportation (1921) at ch. 4 presents a similar but more detailed explanation of the factors that contribute to declining average cost in railroading. Also of interest is his treatment of "ruinous competition" in ch. 5.

${ }^{16}$ U.S. Census Office, Department of the Interior, Cast Iron Pipe Industry, in Report on Manufacturing Industries in the United States: 1890, Part III, Selected Industries 487. 
to be of large capacity, while the new mills in Pennsylvania and New Jersey were of small capacity. This and the somewhat lower pig-iron prices that the southern firms enjoyed led them to be considered the low-cost producers. The mill at Anniston, Alabama, was built in 1889 and, according to one authority, was "the largest pipe and foundry in the world at the time of its building." 17

Table 1 summarizes the characteristics of cast-iron pipe producers as presented in the special study in the 1890 census report. The New Jersey firms were apparently the largest on average, and several had two or more plants of various vintages at the same site or a few miles apart. They seem also to have produced a lower fraction of nonpipe output, probably because there were other foundries in the Northeast that specialized in the production of pipe fittings, gates, valves, and related products. The New Jersey firms sold a substantial fraction of their output abroad. Although the firms in Ohio and the South were remarkably similar, on average, in size and in composition of output, this conceals the diversity of plant sizes in the South. The plants in Texas and Virginia were small, while those in Kentucky, Tennessee, and Alabama were fairly large.

A significant feature of the industry was that output was expensive to transport. Cast-iron pipe was priced at $\$ 15-\$ 30$ per ton f.o.b. (this varied with the price of pig iron), while transportation costs ranged from $\$ 2$ to $\$ 6$ per ton, depending on the distance. Plants were also clustered because of site advantages. In the mid-1890s, for example, four of the six Addyston defendants were located in northern Alabama and southeastern Tennessee. They sold very little of their output in the South but did sell a considerable amount to the growing cities of the Midwest such as Chicago and Milwaukee. They had lower production costs, and the substantial shipping costs for pipe, which did not increase in proportion to distance shipped, made it difficult for firms in the East or even Ohio to compete. Since these few firms were located so close together, and since they had a common natural market, the effect was to accentuate the problems posed by fixed costs that might, under other circumstances, be less severe. Note also that this clustering of several independent plants does not imply that the largest plant has exhausted the economies of scale.

\section{The Types of Plant Cost}

Four of the defendants in Addyston merged in 1898, forming American Pipe and Foundry, and in 1899 United States Cast Iron Pipe and Foundry (USCIP \& F) was formed by adding the two remaining defendants and five

17 Noble, supra note 14 , at 74. 


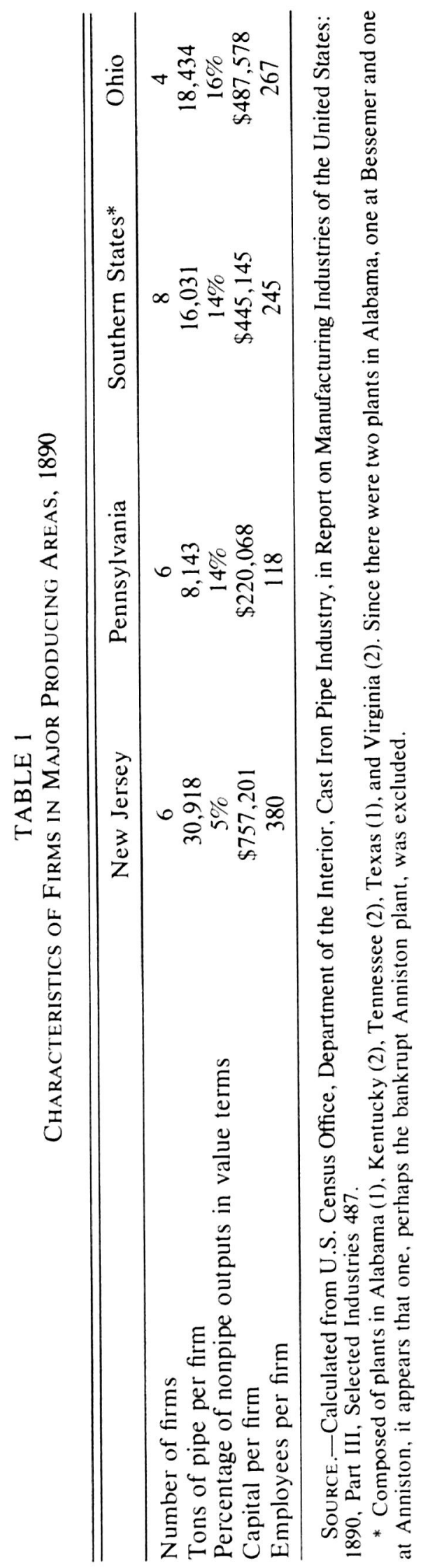


other firms. Two defendants had two-plant operations, and one additional plant was added in 1900. The data which we have cover the twelve-month period beginning in June 1905. At this time USCIP \& F had fourteen plants, of which three were permanently shut down. Two plants, located at Buffalo, New York, and West Superior, Wisconsin, were operated during only some of these twelve months. The other nine operating plants were located in each of the industry's three major producing areas: the Delaware River Valley (where USCIP \& F had one plant); Ohio, northern Kentucky, and western Pennsylvania (five plants); and northern Alabama and southern Tennessee (three plants). By this time several new firms had established themselves in Ohio and in the South, particularly in Birmingham. The other firms in the industry all operated at only one or two sites.

The data are monthly figures on sales, output, inventory, direct and indirect costs, and eleven other series for each of the eleven operating plants owned by USCIP \& F. These figures refer only to the production of cast-iron pressure pipe and exclude the small amounts of related foundry items produced. Although the data cover what Iron Age called the "banner year in the Cast Iron Pipe business, " 18 there was still a substantial variation in output during this period. In particular, the total output of the plants-especially the smaller ones located in the North-dropped during the winter months. This was no doubt due to the fact that water pipe cannot be put down in the North during that period. Variation in the total amount produced was in large part the result of plant shutdowns and reductions in output at the small and medium-sized plants. The large plants, which tended to have lower average accounting costs, had lower proportional changes in output.

Let us consider four types of cost. First, there was the cost of pig iron. We ignore this category of cost because pig iron was used in constant proportion to output. The cost of iron per ton was roughly two-thirds of the total cost, at the factory gate, of output per ton. Second, there were the direct costs, largely labor and fuel. These also tended to vary in proportion to output, although there appears to have been some economy involved if the plant was operated at full capacity. Third, there were indirect costs, which included insurance, taxes, and certain salaries but which were mainly attributable to repair and replacement of equipment. The monthly data reveal that indirect costs were sometimes positively related to output, although not as strongly as direct costs, and in other cases negatively related. The fourth type of cost is inventory cost, which is itself composed of the costs of maintaining output inventory and input

18 Iron Age, May 24, 1906, at 1698. 
inventory. Supply inventories, as is well known, are a major source of economies. Note that output inventories are also inconsistent with the assumption of constant costs in production.

For the moment, the focus will be the plant at Louisville, which may be thought of as the representative plant. It is of medium size, not located too far north or south, and exhibits an average degree of variability in its sales, output, and other series. Eight monthly data series compiled from records of USCIP \& F are presented in Table 2. If we focus on the first four columns (sales, inventory, output, and iron used, all in tons), several patterns emerge. First, sales are not steady through the year but dip severely in the winter months. It is important to emphasize that this figure represents the tonnage of pipe leaving the plant each month ("net sales at the works") and not the tonnage which the firm had promised that month to deliver. ${ }^{19}$ The slack period from December to March resulted because cast-iron pipe could not be installed in northern regions. The variability of output is less than for sales. It never reached the same low levels as sales, nor did it match the peak monthly sales figure. This is one type of evidence that would tend to support the view that these plants did not have constant average costs.

The next set of figures in Table 2 that are of immediate interest are the direct (labor and materials) and indirect (repair and replacement) costs. Although a glance at the figures will not reveal this, direct costs are more closely related than indirect costs to monthly output levels. The coefficient of correlation between output and direct costs is .860 , and between output and indirect costs -.343 . These are not, however, the only costs at the plant. The plants also incurred inventory costs for several thousand tons of output and pig iron and for other materials such as coal, coke, and machine parts. None of this should be surprising, and in fact the results here will confirm "the frequent conviction of entrepreneurs that they are producing under conditions of diminishing average cost." ${ }^{20}$ The standard books on foundry accounting practice, presumably written by those in the best possible position to know what foundry costs look like, also insist that decreasing average cost is a fact of life. ${ }^{21}$

\footnotetext{
19 "Net sales at the works" formed part of stock-flow calculation. New production ("yield" in Table 3) was added to the previous end-of-month inventory and net sales were subtracted from this sum to obtain the new end-of-month inventory. The reader can easily check this in Table 3. This suggests that "net sales" refers to the amount that left the plant"s yard. Whether the firm also received payment that month is another matter, and the ledger offers no clue about this. The terms for municipal contracts were probably fairly standard, although there are some instances in which firms offered two bids, the lower bid to apply if payment was made before a certain date.

20 John Hicks, Value and Capital (1939) at 82.

${ }^{21}$ See, for example, Robert E. Belt, Foundry Cost Accounting (1926) at 54-55.
} 
DECREASING AVERAGE COST

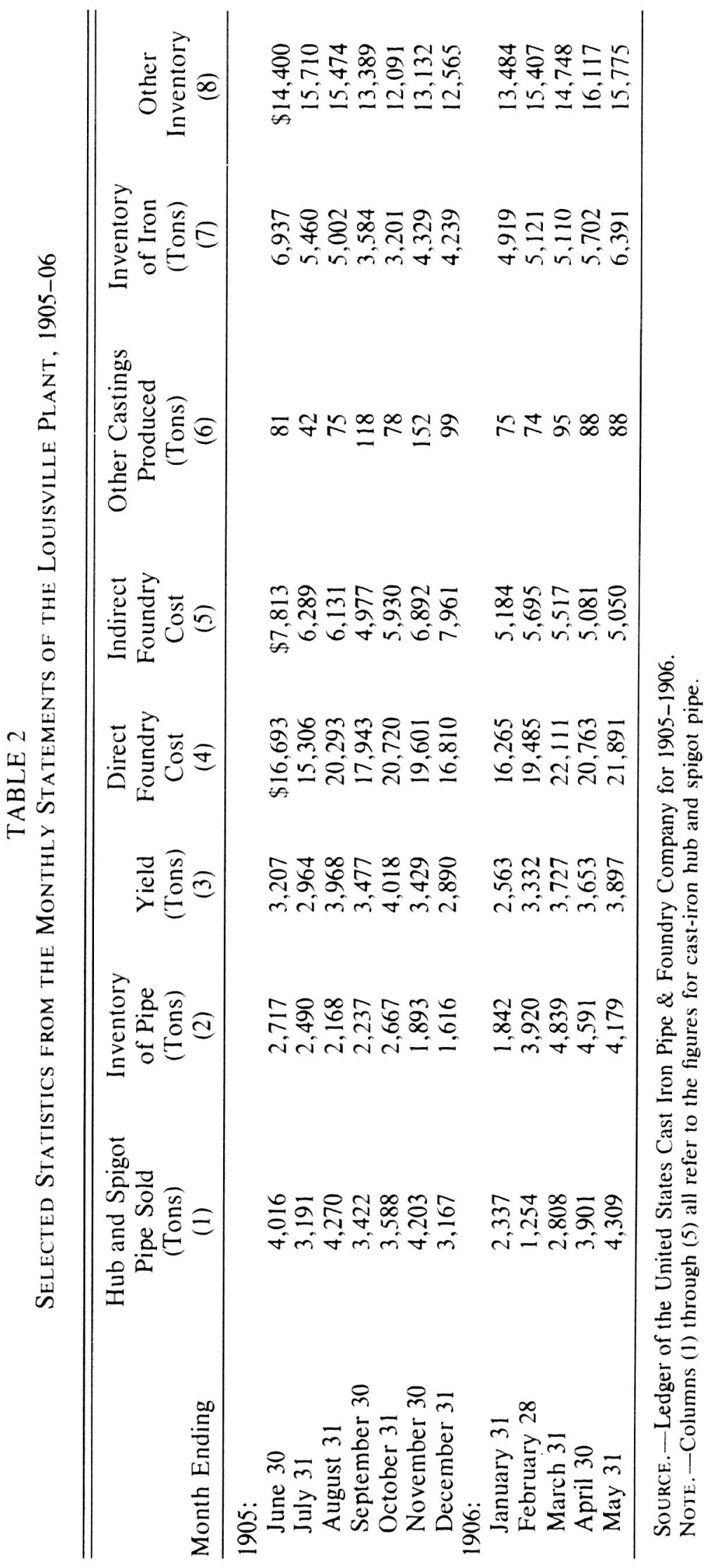




\section{Costs and OUtPut}

Table 3 shows the location, maximum monthly output, and some of the elements of production cost for each plant. Plant size, as measured by maximum output, varied by a factor of nine, from 776 tons for West Superior to 7,224 tons for Addyston. The smallest plant was clearly a high-cost, peak-load unit, as were the other two small northern plants at Columbus and Buffalo. Interestingly, their peak monthly output rates $(1,433$ and 2,157 tons) were roughly two and three times that of West Superior. The next group of plants falls in the range from 3,740 to 4,269. There were four of these. The four largest plants, Addyston, Bessemer, Burlington, and Scottdale, had capacities that fell roughly between 5,300 and 7,300 tons. The most striking feature of Table 3 is the inverse association between capacity and direct and indirect costs.

Probably the leading influence on plant location was the cost of pig iron. This varied from about $\$ 12-\$ 13$ per ton for the three firms located in the South to nearly $\$ 15$ per ton for the firms located in Pennsylvania and northern Ohio. A large part of the output of the southern firms was exported to other areas, chiefly to industrialized parts of the Midwest and to western states, as well as abroad. The lower cost of pig iron contributed to the southern firms' tendency to export to other regions, especially since they had no particular advantage in terms of direct and indirect costs. The plant at West Superior, Wisconsin, probably continued to operate despite its higher per-unit production costs because, when transportation costs are considered, it could still supply the northern plains states and southcentral Canada at a lower price.

An important result in Table 4, which presents the means and coefficients of variation for several series, is that in all cases but those two in which the plants shut down, the coefficient of variation was higher for sales than for output. Again, this indicates the existence of some optimum range of output that firms attempted to maintain. Furthermore, fluctuations in aggregate firm output were disproportionately borne by the small northern plants. The larger northern firms (Addyston, Burlington, and Scottdale) had very little output variation but large inventory holdings. Note also that output has a coefficient of variation very similar to that for direct cost, although slightly smaller in most instances. Indirect cost, on the other hand, takes on more proportional variability than output, except again in the case of the two firms that shut down for part of this period and in the case of Chattanooga, where output was very nearly constant to begin with.

The strong positive relationship between output and direct cost can be seen in the correlations between output and direct cost in Table 5. This 


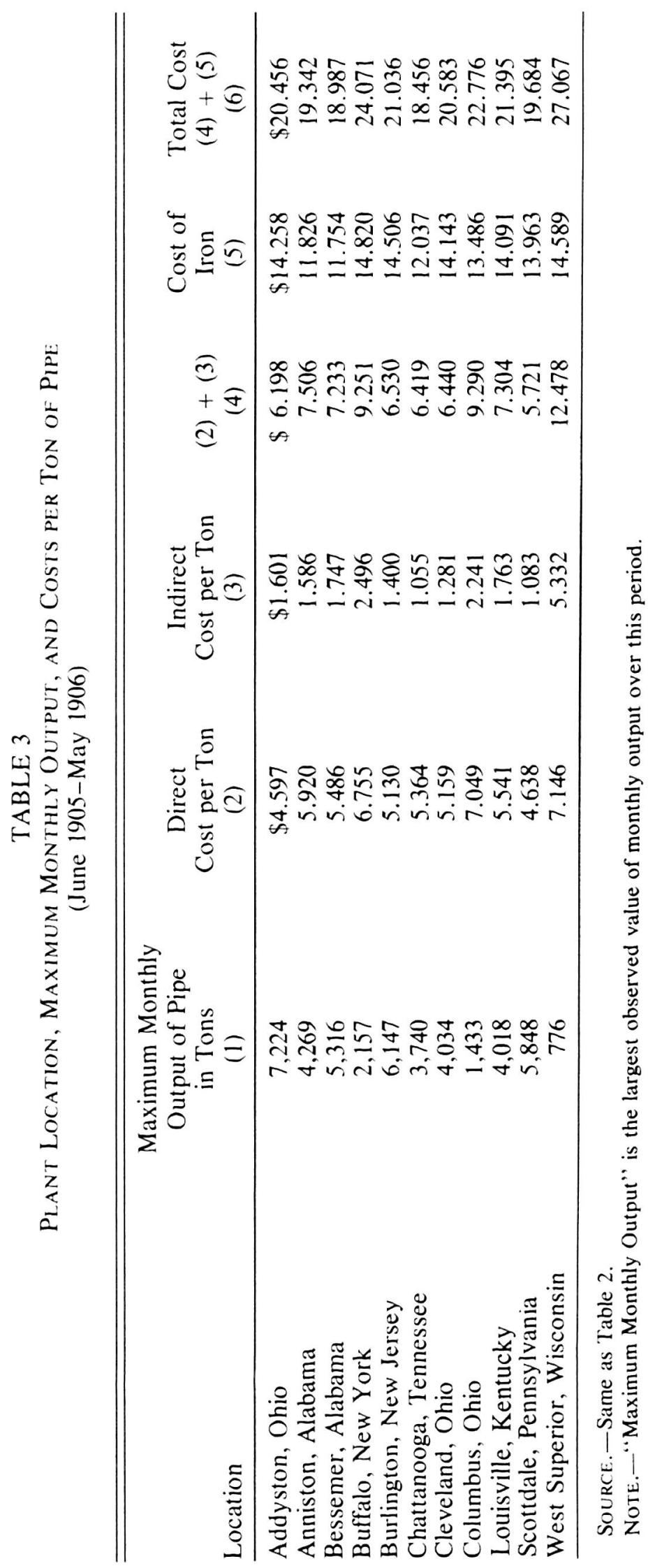




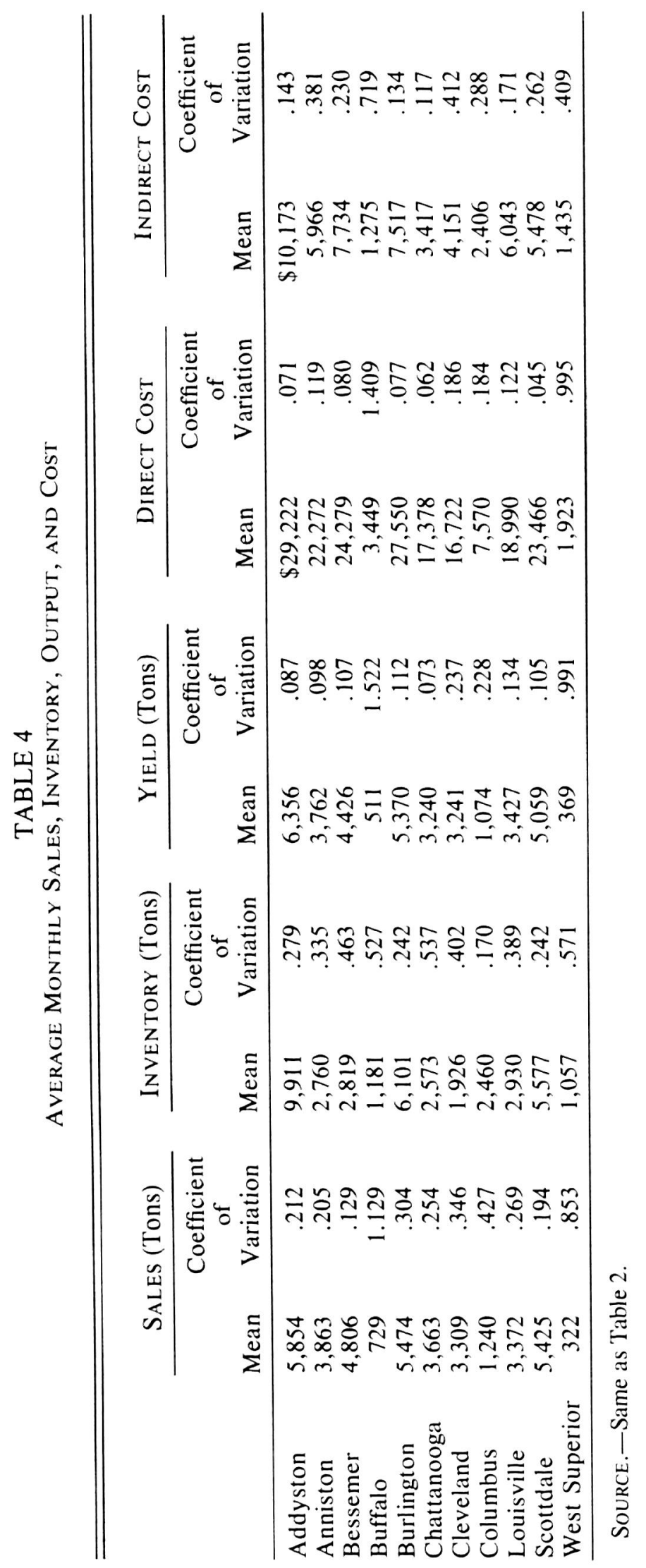


TABLE 5

Relationship of OUtPut to Direct and Indirect Costs

\begin{tabular}{lcc}
\hline \hline & \multicolumn{2}{c}{ CoefFicients OF CORRELATION } \\
\cline { 2 - 3 } Plant & $\begin{array}{c}\text { Output and } \\
\text { Direct Cost }\end{array}$ & $\begin{array}{c}\text { Output and } \\
\text { Indirect Cost }\end{array}$ \\
\hline Addyston & .428 & .130 \\
Anniston & .718 & -.258 \\
Bessemer & .841 & .313 \\
Buffalo* & .994 & .685 \\
Burlington & .911 & -.500 \\
Chattanooga & .532 & .575 \\
Cleveland & .942 & -.664 \\
Columbus & .889 & .806 \\
Louisville & .860 & -.343 \\
Scottdale & .550 & .188 \\
West Superior* & .959 & .717 \\
\hline
\end{tabular}

Source.- Same as Table 2.

NOTE. - These computations are based on twelve monthly observations unless noted otherwise.

* Buffalo had zero output for six out of the twelve months and West Superior had zero output for five out of the twelve months. Consequently, their correlations are based on six and seven observations.

relationship is somewhat attenuated in the case of the four plants with the least output fluctuation (Addyston, Anniston, Chattanooga, and Scottdale). The fact that we can obtain rather high correlations for the remaining plants does suggest that the costs included in this category are part of what one normally thinks of as variable costs.

Indirect costs showed considerably less consistency. For the smaller plants, which experienced long and wide swings in output, an association between the level of output and indirect costs is evident (Buffalo and Columbus, for example). This suggests that for some sufficiently long span of time these costs can be varied, although they were in fact never brought to zero. (Even plants which were shut down the whole year had substantial indirect costs.) However, where there was steadier output, indirect costs showed no correlation or even a negative correlation with output. The negative correlation is especially plausible for a plant running at full capacity most of the time, since repairs would be deferred to those periods when production was slack..$^{22}$

22 This interpretation of the pattern of indirect expenditures is supported by the figures for monthly average cost. Average indirect cost rose sharply in the winter months for most plants, and in several cases the absolute level of indirect cost peaked there. Average direct costs are also higher in the winter, but not in the same pronounced fashion. This tendency of direct costs to rise may have been due in part to the tendency of firms to make smaller pipe sizes for inventory in the winter. This issue is addressed in the next section. For a more detailed discussion, see my dissertation, supra biographical note, at 147-50. 
Finally, it should be noted that the period covered by our numbers was one in which a remarkable expansion of plant capacity took place (altogether three new plants were built in Alabama in 1905 and 1906) and existing foundries produced at unusually high rates. ${ }^{23}$ If it is true that plants do typically operate over the range for which average costs rise, we should be able to find evidence of it in these data.

\section{Estimation of Short-Run Cost Functions}

The data we have for these plants, while remarkably detailed, are unfortunately limited to twelve observations. This will necessarily restrict the analysis to costs that are closely related to current output; however, if "direct cost" is essentially the same as the economist's "variable cost," we have what we are looking for. Substantially longer series would be needed to investigate a model of inventory holdings or depreciation expense.

Tabie 6 presents the results from a regression of the natural log of direct cost on the natural $\log$ of output $(\ln Q)$ and a trend variable. ${ }^{24}$ The coefficients on $\ln Q$ are low, especially for those plants, such as Chattanooga and Scottdale, that had small variations in output. These coefficients, most of which are significantly less than one, might be interpreted as evidence of declining average variable cost. But low coefficients tend to occur where output variation is low, so it might be the case that we have an errors-in-variables problem. However, this regularity is also consistent with omitted variables bias. For example, larger pipe is cheaper to produce per ton than smaller pipe. If small pipe sizes are produced when output is low, this could bias the coefficient. It is also possible that pipe of any given size may be cheaper to produce under certain conditions, perhaps when aggregate demand is high and work can be scheduled more efficiently. This suggests that we might try to isolate variables that are correlated, not only with our omitted variables, but also with output. We use a two-step procedure in which the log of actual output is regressed on the lagged values of variables associated with the state of the economy, where these are also expressed in log form. The predicted value of output implied by the regression results is then used as an additional explanatory

${ }^{23}$ See the reports in Iron Age from its New York and Birmingham correspondents throughout this period.

${ }^{24}$ An understandable objection to these regressions is that a sample size of twelve is fairly small. My alternative, however, was to not use the data at all. Since the statistical results here are in close agreement with results from other industries, it seemed sensible to present them. Moreover, these findings are not crucial to the analysis but simply corroborate and extend the evidence in Sections IV through VI. 
TABLE 6

Ordinary Least Squares Estimates of Plant Cost Functions Log of Direct Costs Regressed on Log of OUtPuT

\begin{tabular}{|c|c|c|c|c|c|c|}
\hline Plant & Intercept & $\ln Q$ & Time & $\begin{array}{c}\text { Durbin-Watson } \\
d \text {-Statistic }\end{array}$ & SSE & $R^{2}$ \\
\hline Addyston & $\begin{array}{c}5.34 \\
(5.75)\end{array}$ & $\begin{array}{c}.55 \\
(5.22)\end{array}$ & $\begin{array}{r}.017 \\
(6.56)\end{array}$ & 2.25 & .0081 & .86 \\
\hline Anniston & $\begin{array}{c}3.47 \\
(1.56)\end{array}$ & $\begin{array}{c}.79 \\
(2.88)\end{array}$ & $\begin{array}{r}.010 \\
(1.36)\end{array}$ & 1.60 & .0628 & .61 \\
\hline Bessemer & $\begin{array}{c}5.02 \\
(5.86)\end{array}$ & $\begin{array}{c}.60 \\
(5.84)\end{array}$ & $\begin{array}{l}.008 \\
(2.56)\end{array}$ & 1.53 & .0115 & .85 \\
\hline Burlington & $\begin{array}{c}4.82 \\
(6.28)\end{array}$ & $\begin{array}{c}.63 \\
(7.10)\end{array}$ & $\begin{array}{l}.005 \\
(.15)\end{array}$ & 2.72 & .0102 & .87 \\
\hline Chattanooga & $\begin{array}{c}6.40 \\
(3.05)\end{array}$ & $\begin{array}{c}.41 \\
(1.58)\end{array}$ & $\begin{array}{l}.003 \\
(.53)\end{array}$ & 1.75 & .0298 & .32 \\
\hline Cleveland & $\begin{array}{c}3.69 \\
(8.20)\end{array}$ & $\begin{array}{c}.74 \\
(13.52)\end{array}$ & $\begin{array}{r}.011 \\
(2.39)\end{array}$ & .85 & .0236 & .95 \\
\hline Columbus & $\begin{array}{c}2.21 \\
(4.41)\end{array}$ & $\begin{array}{r}.94 \\
(13.54)\end{array}$ & $\begin{array}{r}.025 \\
(5.62)\end{array}$ & 1.87 & .0161 & .96 \\
\hline Louisville & $\begin{array}{c}4.07 \\
(7.40)\end{array}$ & $\begin{array}{c}.70 \\
(10.27)\end{array}$ & $\begin{array}{r}.016 \\
(6.08)\end{array}$ & 2.33 & .0086 & .95 \\
\hline Scottdale & $\begin{array}{c}5.95 \\
(4.87)\end{array}$ & $\begin{array}{c}.48 \\
(3.38)\end{array}$ & $\begin{array}{r}.009 \\
(2.21)\end{array}$ & 2.37 & .0099 & .56 \\
\hline
\end{tabular}

Note. - The number of observations is twelve in each case, and parentheses indicate $t$-statistics. The Durbin-Watson $d$-statistic is intended here as in the other tables to be suggestive rather than definitive. Standard tables give confidence intervals only for $N \geqslant 15$. "Time" is a trend variable that takes on the values $1,2,3, \ldots, 12$.

variable in the estimation of the cost function. This is related, of course, to the instrumental variables approach, the difference being that we use both the actual and the "predicted" values of $\ln Q .{ }^{25}$

25 The four exogenous variables are lagged monthly values of factory employment, pigiron production, railroad freight ton-miles, and building permits. Estimates using current values of these variables give essentially the same results. This method of estimation is related to a test for simultaneous equation bias proposed by J. A. Hausman, Specification Tests in Econometrics, 46 Econometrica 25 (1978). This technique is directed at the first of two errors-in-variables problems, namely, that "true output" is measured with error because the mix of pipe sizes varies from month to month and may vary with output. The second possible errors-in-variables problem arises if resources ("costs") are committed before output is produced and output itself is a random variable. So, for example, a plant may intend to produce the same amount of output each month and hire the same amount of resources but find that actual output fluctuates because of random forces. An econometric investigation of the plant's cost function would mistakenly infer zero marginal costs. I have not dealt with this possible source of downward bias because the output changes at the plants are substantial and seem to have been deliberate. To a large extent they were in response to seasonal variations in demand. The statistical issue is discussed in a slightly different context in Milton Friedman, Comment, in Business Concentration and Public Policy (1955). Similar concerns also arise in the case of production functions. See Yair Mundlak and Irving Hoch, Consequences of Alternative Specifications in Estimation of 
TABLE 7

Two-Stage Estimates of Plant Cost Functions

Log of Direct Costs Regressed on Log of Output and Predicted LOG OF OUTPUT

\begin{tabular}{|c|c|c|c|c|c|c|c|}
\hline Plant & Intercept & $\ln Q$ & $\ln \dot{Q}$ & Time & $\begin{array}{c}\text { Durbin- } \\
\text { Watson } \\
d \text {-Statistic }\end{array}$ & SSE & $R^{2}$ \\
\hline Addyston & $\begin{array}{c}4.09 \\
(1.87)\end{array}$ & $\begin{array}{r}.50 * \\
(3.54)\end{array}$ & $\begin{array}{l}.20 \\
(.64)\end{array}$ & $\begin{array}{r}.019 \\
(4.88)\end{array}$ & 2.47 & .0077 & .87 \\
\hline Anniston & $\begin{array}{l}1.70 \\
(.31)\end{array}$ & $\begin{array}{c}.75 \\
(2.42)\end{array}$ & $\begin{array}{l}.26 \\
(.36)\end{array}$ & $\begin{array}{r}.009 \\
(1.08)\end{array}$ & 1.79 & .0619 & .62 \\
\hline Bessemer & $\begin{array}{c}6.83 \\
(6.26)\end{array}$ & $\begin{array}{r}.76^{*} \\
(6.77)\end{array}$ & $\begin{array}{c}-.37 \\
(-2.20)\end{array}$ & $\begin{array}{c}.008 \\
(3.14)\end{array}$ & 1.47 & .0072 & .90 \\
\hline Burlington & $\begin{array}{c}5.35 \\
(2.27)\end{array}$ & $\begin{array}{r}.64^{*} \\
(5.63)\end{array}$ & $\begin{array}{c}-.076 \\
(-.24)\end{array}$ & $\begin{array}{l}-.001 \\
(-.11)\end{array}$ & 2.71 & .0101 & .87 \\
\hline Chattanooga & $\begin{array}{l}13.50 \\
(5.91)\end{array}$ & $\begin{array}{c}.82 \\
(4.18)\end{array}$ & $\begin{array}{c}-1.29 \\
(-3.82)\end{array}$ & $\begin{array}{r}.009 \\
(2.37)\end{array}$ & 1.21 & .0106 & .76 \\
\hline Cleveland & $\begin{array}{c}3.87 \\
(3.18)\end{array}$ & $\begin{array}{r}.74 * \\
(10.68)\end{array}$ & $\begin{array}{r}-.027 \\
(-.16)\end{array}$ & $\begin{array}{r}.010 \\
(1.38)\end{array}$ & .82 & .0235 & .95 \\
\hline Columbus & $\begin{array}{c}3.22 \\
(2.70)\end{array}$ & $\begin{array}{c}.99 \\
(10.11)\end{array}$ & $\begin{array}{c}-.19 \\
(-.76)\end{array}$ & $\begin{array}{r}.018 \\
(1.86)\end{array}$ & 2.04 & .0150 & .96 \\
\hline Louisville & $\begin{array}{c}5.25 \\
(7.80)\end{array}$ & $\begin{array}{r}.81^{*} \\
(11.02)\end{array}$ & $\begin{array}{c}-.26 \\
(-2.35)\end{array}$ & $\begin{array}{c}.016 \\
(7.28)\end{array}$ & 1.76 & .0051 & .97 \\
\hline Scottdale & $\begin{array}{l}8.59 \\
(4.55)\end{array}$ & $\begin{array}{r}.63 * \\
(4.04)\end{array}$ & $\begin{array}{r}-.46 \\
(-1.73)\end{array}$ & $\begin{array}{l}.003 \\
(.48)\end{array}$ & 2.56 & .0072 & .68 \\
\hline
\end{tabular}

NOTE.-The remarks at Table 6 apply. An asterisk indicates that the coefficient is significantly different from one at the 5 percent level.

Table 7 presents the results from this method. Note that the coefficient on quantity for Bessemer, Chattanooga, Louisville, and Scottdale is greater here than for the earlier equations based on $\ln Q$ alone. Moreover, the coefficient for $\ln Q$ is significantly different from zero and negative in these four cases. This suggests that the low estimates arrived at earlier were due to the exclusion of factors that were correlated with quantity but that exerted an independent negative influence on costs. Since large pipe was cheaper to produce per ton, and since large pipe tended to be produced in the spring and during upswings in the business cycle, lower costs per ton associated with increases in a $\ln Q$ (which is simply a linear combination of the logs of several aggregate variables) might simply reflect the lower cost for large pipe. For the other plants, our estimates resulted in coefficients that are essentially unchanged from what OLS provided.

Cobb-Douglas Production Functions, 33 Econometrica 814 (1965), and Arnold Zellner, J. Kmenta, and J. Dréze, Specification and Estimation of Cobb-Douglas Production Function Models, 34 Econometrica 784 (1966). 
TABLE 8

Capacity, and Marginal. and Average Direct Costs

\begin{tabular}{lcccc}
\hline \hline & $\begin{array}{c}\text { Capacity } \\
\text { (Maximum } \\
\text { Monthly Output) } \\
(1)\end{array}$ & $\begin{array}{c}\text { Coefficient } \\
\text { on In } Q \\
(2)\end{array}$ & $\begin{array}{c}\text { Average } \\
\text { Direct Cost } \\
(3)\end{array}$ & $\begin{array}{c}\text { Estimated } \\
\text { Marginal Cost } \\
(4)\end{array}$ \\
\hline Addyston & 7,224 & .50 & $\$ 4.60$ & $\$ 2.30$ \\
Anniston & 4,269 & .75 & 5.92 & 4.44 \\
Bessemer & 5,316 & .76 & 5.49 & 4.17 \\
Burlington & 6,147 & .64 & 5.13 & 3.28 \\
Chattanooga & 3,740 & .82 & 5.36 & 4.40 \\
Cleveland & 4,034 & .74 & 5.16 & 3.82 \\
Columbus & 1,433 & .99 & 7.05 & 6.98 \\
Louisville & 4,018 & .81 & 5.54 & 4.49 \\
Scottdale & 5,848 & .63 & 4.64 & 2.92 \\
\hline
\end{tabular}

Note. - The correlation between columns (1) and (2) is -.964 , between (1) and (3) -.875 , and (1) and (4) -.948

A curious empirical regularity emerges from the results in Table 8 . It turns out that there is a very startling relationship between the estimated coefficient on $\ln Q$ and the size of a plant. Using maximum monthly output as our measure of plant size, we find that the coefficient of correlation between plant size and this estimate is -.964 . Since the cost functions are of the form $C=A Q^{\beta}$, marginal cost is equal to $\beta A Q^{\beta-1}$ or $(C / Q) \beta$ (i.e., average cost times $\beta$ ). Consequently, as Table 8 reveals, larger plants not only have lower average direct costs but lower marginal direct costs as well.

A diagrammatic exposition of this situation is presented in Figure 2. We see that it is possible to obtain lower average direct costs, but only by sacrificing some flexibility. An economic reason for this might be that large plants rely more on institutional arrangements and explicit delineation of duties to organize workers. Consequently, changes in the rate of production are more difficult for large plants, because positions and responsibilities have to be created, removed, or modified as output is changed. These are expenses a firm will not gladly endure for short-run changes. Regardless of the particular causes, this appear to be a finding that has a place in economic reasoning. George Stigler suggests that firms adapt to uncertainty by using technologies that are flexible ${ }^{26}$ One way of adapting, of course, is by flattening average cost curves. According to the results here, another way of meeting variable demand is by constructing

${ }^{26}$ George Stigler, Production and Distribution in the Short Run, 47 J. Pol. Econ. 305 (1939). 


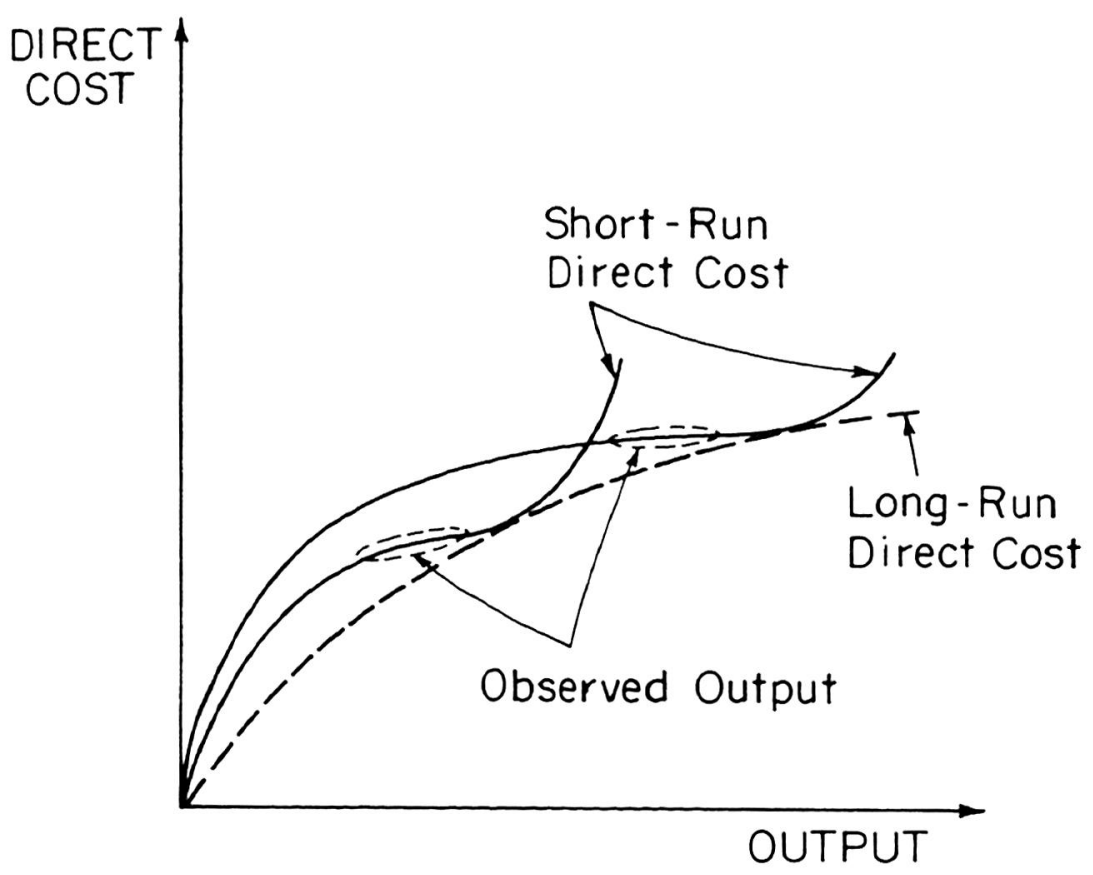

Figure 2

some smaller plants which have more flexibility in their use of labor and fuel but which as a result have higher costs, including higher marginal costs. ${ }^{27}$

One more technical step is possible with these data. It is, of course, very likely that even after we have taken into account the effect of actual output and expected output on costs, some factors determining costs have been neglected. If these factors are common across several or all plants, it might be useful to employ one of the methods developed for handling seemingly unrelated regressions. The method used here is the generalized-least-squares approach to seemingly unrelated regressions proposed by Arnold Zellner. ${ }^{28}$ This method uses the estimated variancecovariance matrix of residuals obtained from the ordinary least squares estimation of each equation. Results from this technique are shown in Table 9, where we see that the salient features of our earlier estimates are preserved. Moreover, a one-tailed test of the hypothesis that the true

${ }^{27}$ The view that small plants are more flexible is supported by other data. Recall that Table 5 contains the coefficients of correlation between output and indirect (repair and replacement) costs. The relationship between these two series is clearly strongest at Chattanooga and Columbus and at the two plants we have excluded from our regressions because they were shut down part of the time. These are also the four smallest plants of the eleven, indicating that so far as indirect costs are concerned, these costs at small plants had a lower fixed or lump-sum element.

${ }^{28}$ Arnold Zellner, An Efficient Method of Estimating Seemingly Unrelated Regressions and Tests for Aggregation Bias, 57 J. Am. Statistical Assoc. 348 (1962). 
TABLE 9

Three-Stage Seemingly Unrelated Estimates of Plant Cost Functions Log of Direct Costs Regressed on log of Actual and log of Predicted Output

\begin{tabular}{lcccc}
\hline \hline Plant & Intercept & $\ln Q$ & \multicolumn{1}{c}{$\widehat{\ln Q}$} & \multicolumn{1}{c}{ Time } \\
\hline Addyston & 2.77 & $.52^{*}$ & .32 & .020 \\
Anniston & $(1.83)$ & $(6.87)$ & $(1.53)$ & $(6.25)$ \\
& 6.07 & .75 & -.28 & .012 \\
Bessemer & $(1.46)$ & $(5.31)$ & $(-.52)$ & $(1.51)$ \\
& 7.13 & $.82^{*}$ & -.47 & .008 \\
Burlington & $(8.89)$ & $(9.49)$ & $(-3.65)$ & $(3.14)$ \\
& 5.17 & $.62^{*}$ & -.035 & -.0002 \\
Chattanooga & $(3.29)$ & $(11.67)$ & $(-.18)$ & $(-.050)$ \\
Cleveland & 12.72 & $.67^{*}$ & -1.04 & .008 \\
& $(9.41)$ & $(5.35)$ & $(-5.12)$ & $(2.49)$ \\
Columbus & 2.94 & $.77^{*}$ & .64 & .014 \\
& $(3.05)$ & $(15.18)$ & $(.47)$ & $(2.19)$ \\
Louisville & 4.50 & 1.04 & -.42 & .010 \\
& $(3.88)$ & $(17.17)$ & $(-2.21)$ & $(1.20)$ \\
Scottdale & 5.56 & $.86^{*}$ & -.34 & .015 \\
& $(10.67)$ & $(16.68)$ & $(-4.36)$ & $(7.25)$ \\
& 9.23 & $.66^{*}$ & -.56 & .001 \\
& $(7.40)$ & $(8.47)$ & $(-3.54)$ & $(.24)$ \\
\hline
\end{tabular}

Note. - The remarks at Tables 6 and 7 apply.

value of the returns parameter is equal to one can be rejected at the 5 percent level for all plants but Anniston and Columbus. These results imply that average variable or direct cost decreased with increases in output, and this carries with it the conclusion that monthly output rates were in the range over which total average cost was falling.

One more point should be mentioned. Some elements of indirect cost such as repairs to machinery and equipment were incurred at positive output rates, but not if plants were shut down only temporarily. The daily repair of the cupola is an example of this. Since we excluded such items, the fixed avoidable cost is probably much greater than our figures on direct costs suggest. It is true that we could have added indirect costs to direct costs and used this sum to estimate a "particular expenses" function. Unfortunately, this technique would also make estimation more difficult since, as we saw, indirect costs as a whole bear no necessary relationship to output and may even be negatively related. Yet, especially with this sort of finding for indirect costs, and remembering that we have not incorporated the expense of inventory in our measure of costs, these results provide strong support for the view that incremental variable costs for these plants were less than average variable costs. ${ }^{29}$

29 The results in this section are consistent with other work on cost functions. See the extensive survey by A. A. Walters, Production and Cost Functions, 31 Econometrica 1 (1963). 


\section{Conclusions}

This study has been devoted to the investigation of a syllogism which begins: Increasing returns are incompatible with competition. This premise has been the subject of extensive theoretical work and stands largely unchallenged. One exception occurs if there are no costs to having idle plants and an infinite number of plants stand ready to satisfy a particular rate of demand at minimum average cost. In the more realistic case where there are some fixed costs, the existence of falling short-run average cost will imply that there can be no competitive solution to the problem of allocation in the market, a problem recognized since Viner first presented his analysis of $U$-shaped average cost curves. In the case where falling average cost is a consequence of expenses that cannot be avoided in the short run, familiar results from the study of natural monopolies tell us that marginal cost pricing, which is what competition implies, will not sustain the industry.

The application of these findings demands some care, because the theoretical models are not perfect representations of actual markets. For example, the models assume that recontracting is costless and that all plants are located at a single point. Yet it seems reasonable that slight deviations from the point at which a competitive equilibrium exists will not create major difficulties if it is costly to shop around. The dispersion of plants seems at first glance to work the same way, but the effect of transportation costs is actually to cluster plants in small groups. Typically, several plants are located close together because of some site advantage. (For example, the six Addyston defendants were located near the Alabama-Tennessee border and along the Ohio River and sold nearly half their output in the mid-1890s to the Chicago area alone.) In such cases, we can treat a group of firms as though they were located at the same spot and supplying a distinct area. This accentuates the problems for competition since each plant has a comparatively large share of the relevant market. These observations do suggest why this industry ran into real difficulty only when conditions got bad, as they did all through the 1890 s, since the normal market frictions were not sufficient to ensure stability.

The second premise in this syllogism is that cast-iron pipe manufacture was carried out under increasing returns, and I have given considerable attention to the nature of costs in this industry. This attention is justified because detailed plant cost data are rare, because new facts concerning Addyston deserve a thorough presentation, and because the nature of costs lies at the heart of the analysis. The major results are: (1) average direct and indirect costs are larger at smaller plants; (2) a substantial portion of monthly plant costs does not depend on current output; and (3) 
there is no evidence of rising marginal cost and in fact the plants typically operated under conditions of falling marginal cost. These cost conditions are inconsistent with any rigorously defined notion of competition.

There is much more that can be said about Addyston and the issues it raises. For example, the reason we know so much about this case is that a stenographer copied cartel documents in the hope that the cartel's buyers would sue, using his evidence, and share the damages with him. Why did all the cities he contacted refuse his offer, leaving prosecution of the case to the federal attorney? In fact, the purchasers submitted affidavits on behalf of the defendants. Another interesting question arises out of the fact that United States Cast Iron Pipe and Foundry merged following Judge Taft's decision and at the same time that a merger wave that was to involve nearly half of U.S. industrial capacity was picking up steam. What role did judicial interpretation of the Sherman Act and Addyston Pipe play in the formation of USCIP \& F and the merger wave? But these and other questions must be deferred to another time. 